\title{
Identificación de Arcobacter en niños y adultos con/sin diarrea y en reservorios animales: aves, ganado vacuno y porcino, peces y mariscos
}

\author{
Rito Zerpa, Jorge Alarcón, Percy Lezama, Lilian Patiño, Alberto Reyes, Augusto Valencia, \\ Jorge Velásquez, Miriam Alarcón \\ Instituto de Medicina Tropical Daniel A. Carrión, Facultad de Medicina, UNMSM, Instituto Nacional de Salud del Niño, Instituto Materno Infantil de \\ San Bartolomé y Hospital Arzobispo Loayza
}

Objetivos: Conocer la prevalencia de Arcobacter en niños y adultos con/sin diarrea y en animales: aves, ganado vacuno y porcino, peces y mariscos.

Diseño: Estudio transversal descriptivo.

Institución: Instituto de Medicina Tropical Daniel A. Carrión, Facultad de Medicina, UNMSM, Instituto Nacional de Salud del Niño, Instituto Materno Infantil de San Bartolomé y Hospital Arzobispo Loayza.

Material biológico: Aislamientos bacterianos de humanos y animales.

Intervenciones: Búsqueda activa de Arcobacter sp. en humanos y animales.

Principales medidas de resultados: Porcentajes.

Resultados: De 197 niños incluidos en el estudio, 100 tenían diarrea y de estos en dos (2\%) se aisló A. butzleri; entre los niños sin diarrea, no se aisló el germen. De 232 adultos, 52 tuvieron diarrea y 180 no; el único aislamiento se obtuvo de este último grupo. Los animales con mayor prevalencia de Arcobacter sp. fueron los bovinos (25\%) y porcinos (29,2\%). Entre las especies marinas con prevalencias altas: choro $24 \%(12 / 50)$ y langostinos $22 \%(11 / 50)$.

Conclusiones: De acuerdo a los resultados de este estudio, Arcobacter resultó una bacteria zoonótica potencialmente patógena para el ser humano, en particular para los niños, así como hubo presencia de este agente en especies animales utilizadas para el consumo humano.

Palabras clave: Arcobacter, enfermedad diarreica, niños y adultos, reservorios animales.

\section{Ensayo de PCR- RFLP-ITS2 para diferenciar especies del género Anopheles (Diptera: Culicidae) presentes en Perú}

Claudia Núñez, David Ortiz, Víctor Aliaga, Bertha Moreno, Salvador Villegas, Alina Huiza,

Carlos Sevilla, Christian Gonzales, Abraham Cáceres

D. A. Microbiologia Médica, Facultad de Medicina, UNMSM; Centro de Biotecnología, Universidad Iberoamericana de Ciencias y Tecnología; Laboratorio Entomologia Médica, Sección Parasitologia, Instituto de Salud Pública; Laboratorio de Entomología Médica, Laboratorio de Referencia Regional, Gerencia Regional de Salud La Libertad; Dirección Ejecutiva de Salud Ambiental, Sub Región de Salud “Luciano Castillo Colonna”, DIRESA Piura.

Objetivos: Implementar el ensayo PCR-RFLP-ITS2 para diferenciar especies del género Anopheles presentes en distintas localidades del Perú.

Diseño: Descriptivo, observacional.

Institución: D. A. Microbiología Médica, Facultad de Medicina, UNMSM; Centro de Biotecnología, Universidad Iberoamericana de Ciencias y Tecnología; Laboratorio Entomología Médica, Sección Parasitología, Instituto de Salud Pública; Laboratorio de Entomología Médica, Laboratorio de Referencia Regional, Gerencia Regional de Salud La Libertad; Dirección Ejecutiva de Salud Ambiental, Sub Región de Salud "Luciano Castillo Colonna", DIRESA Piura.

Material biológico: Mosquitos del género Anopheles.

Intervenciones: Extracción de ADN de Anopheles

Principales medidas de resultados: Se utilizó 79 ejemplares del género Anopheles de cinco departamentos del país. Se extrajo ADN de una parte de cada mosquito, el que fue utilizado como molde para la amplificación de la región ITS2, producto que fue digerido con dos enzimas de restricción.

Resultados: La digestión de la región ITS2, con las enzimas Alul y Bcll, permitió diferenciar entre especies de este género de mosquitos, al generarse patrones de bandeo diferentes en cada una de las especies.

Conclusiones: La región ITS2 es un marcador molecular que varía en las distintas especies de este género, por lo cual mediante la utilización de este marcador se puede identificar especies tanto en este género de mosquito, como en otros géneros pertenecientes a la misma familia.

Palabras clave: Anopheles, Diptera: Culicidae, PCR-RFLP, ITS-2. 